\title{
Effect of heat stress on the Development of a Flight Maneuver
}

\author{
Efecto del estrés por calor en el desarrollo de una maniobra de vuelo
}

\author{
Z. I. Cuaran-Cuaran iD ; W. M. Fong-Amarís iD ; R. A. López-Pimiento iD, M. Martínez- \\ Lozano iD ; R. Otero-Caicedo iD
}

\begin{abstract}
It has been reported that the decrease in performance of airplane pilots, due to extreme work conditions, could potentially lead to an accident. Additionally, exposure to heat conditions has been linked to increased accident rates. The objective of this experimental study was to examine the influence of temperature $\left(21^{\circ} \mathrm{C}\right.$ and $\left.35^{\circ} \mathrm{C}\right)$ and the maneuver complexity, in the pilots' performance, measured by the time spent to complete a maneuver, using a Static Flight Driving Device simulator. We used an experimental design with ten $(n=10)$ professional pilots who had an average flight experience of 420 hours. The results obtained show that there is an effect of both, temperature and the maneuver difficulty, in the time needed to complete a flight maneuver. Maneuvers that are more complex $(p<.05)$ or expose pilots to heat $(p<.05)$, increase the time to complete a maneuver. Even though the interaction term had a pvalue of 0.103 , what was seen in the experiment suggest that the temperature has a bigger effect when the maneuver is considered difficult.
\end{abstract}

Index Terms-Airplane pilots; maneuver complexity; flight; temperature.

Resumen - Se ha reportado que la disminución en el rendimiento del desempeño de pilotos de aeronave, a causa de condiciones extremas de trabajo, podría conllevar a que ocurra un accidente. Además, se ha demostrado la relación entre la exposición al calor y la ocurrencia de accidentes. El presente estudio experimental

This manuscript was sent on May 04, 2019 and accepted on March 09, 2020. This work was supported by the faculty of engineering at Javeriana University in Bogotá.

Z. I. Cuaran-Cuaran is with the Electronical Engineering Department, Pontificia Universidad Javeriana. Bogotá D.C. - Colombia - Cra. 7 No. 40-62 (e-mail: cuaran_zuleny@javeriana.edu.co)

W. M. Fong-Amarís is with the Electronical Engineering Department. Pontificia Universidad Javeriana. Bogotá D.C. - Colombia - Cra. 7 No. 40-62 (e-mail: we_fong@javeriana.edu.co)

R. A. López-Pimiento is with the Electronical Engineering Department. Pontificia Universidad Javeriana. Bogotá D.C. - Colombia - Cra. 7 No. 40-62 (e-mail: lo_rodolfo@javeriana.edu.co)

M. Martínez-Lozano is with the Electronical Engineering Department. Pontificia Universidad Javeriana. Bogotá D.C. - Colombia - Cra. 7 No. 40-62 (e-mail: marinezl.m@javeriana.edu.co)

R. Otero-Caicedo is with the Industrial Engineering Department. Pontificia Universidad Javeriana. Bogotá D.C. - Colombia - Cra. 7 No. 40-62 (e-mail: r.otero@javeriana.edu.co) tuvo como objetivo analizar la influencia de la temperatura $\left(21^{\circ} \mathrm{C} \mathrm{y} 35^{\circ} \mathrm{C}\right)$ y la complejidad, en el desempeño de los pilotos de vuelo, medido como el tiempo de realización de, empleando un simulador de vuelo estático. Se utilizó un diseño experimental con diez $(n=10)$ pilotos profesionales de aviación con una experiencia de vuelo promedio de 420 horas. Los resultados obtenidos, demuestran la influencia de la temperatura $(p<.05)$ y la complejidad $(p<.05)$ en el tiempo de desarrollo de las maniobras. Aunque el valor $p$ de la interacción fue de 0,013 , lo observado en el experimento sugiere que la temperatura tiene una influencia mayor en los pilotos cuando la maniobra es considerada difícil.

Palabras clave - complejidad de maniobra; pilotos de aeronave, temperatura; vuelo,

\section{INTRODUCTION}

$\mathrm{N}$ OW a day, the aeronautic sector has a direct impact on the three pillars of sustainability, including, economic, social and environmental areas. This is because it is a key aspect in passengers and cargo transportation, and it conducts special aerial work in humanitarian and healthcare. In Colombia, these types of activities are regulated by the RAC (Aeronautic Regulation of Colombia), established by the Special Administrative Unit of Civil Aeronautics [1] in the ordinance 823 of the $16^{\text {th }}$ of May, 2017, where it was declared as the aeronautic authority in the national territory.

The RAC 4 [2] is the document that regulates the Airworthiness and Aircraft Operation Norms where they specify the minimum instruments and equipment that an aircraft needs to flight. It also stipulate the security requirements, and the interior and exterior maintenance guides of an airplane cabin. In that document, they stipulate the test and inspection devices and systems required to guarantee the proper functioning of a cruise flight. A flight instrument that measure the temperature of the exterior air is required, but there is not any kind of suggestion to measure the interior temperature of the pilots' cabin.

In the Colombian context, the Hydrology, Meteorology and Environmental Studies Institute (IDEAM), reports that Colombia has cities with an average temperature between $12.9^{\circ} \mathrm{C}$ and $28.4^{\circ} \mathrm{C}$ [3]. This temperature variation leads to 
extreme microenvironments of heat and cold inside the cabin. Depending on the flight conditions and routes, the change of weather could lead to a cognitive stress that influences the human performance. Even though it is a fact that the pilots confront thermic stress, there are few reports about the effects of environmental temperature in their execution of a psychomotor task [4].

Given the variety of temperatures in the different airports of the country and the temperatures changes in each airport, it is not possible to keep the same temperature inside the cabin. Therefore, there is the need to measure the effect that the temperature inside the cabin could have in activities such as take-off, landing and other complicated maneuvers during flights, because as mentioned by [5] any obstacle associated with temperature stress could be potentially deadly in the aeronautical sector.

Human mistakes in aviation are the principal cause of the aerial accidents and incidents. Apart from causing security problems, it produces financial loss for the aerial industry such as flight delays, gas and damaged aircraft costs [6] [7].

To reduce the human mistakes, the pilots train in flight simulators that replicate the appearance and functioning of the aircraft systems, this device can emulate several flight situations. Current software simulators help to evaluate the pilots' skills and capabilities, without exposing them to height risks during a flight and reducing training time.

Training military pilots includes acrobatic flights with advanced maneuvers that usually contains unexpected changes of speed [1]. In commercial aviation related to passengers or cargo, the maneuvers are mostly basic since it is considered a controlled flight, but, high level of cognitive concentration is required during take-off, landing and some maneuvers during a flight.

Therefore, it is necessary to design experiments to understand the pilots' behavior under the effect of external factors that could intervene in the pilots' cognitive abilities and decrease their capabilities to operate an aircraft. Furthermore, due to it is not possible to run experiments during a real flight, this kind of research must be done under simulated real conditions.

In this research, using a flight simulator and pilots with at least 200 hours of flight experience, it was measured the effect of two levels of temperature under different kinds of maneuvers.

\section{BACKGROUND.}

Stave [8], in a flight simulator carried out a first study where different effects of noise and vibration was examined in the performance of the pilots, and in a second study [9] he evaluated the same aspects in a simulator adding another factor, fatigue. In the first study, he reported that there was no reduction in the performance, but in the second study, he mentioned that there were some short time lapses where the performance was affected. Similar to this study, other authors declared the exposition to noise does not affect significantly the pilot or the task it conducts [10].

Other studies evaluated the factors that can intervene in the spatial disorientation [11], performance, welfare and the health of the pilots [12]. Additionally, [13] evaluated the interaction of factors such as commodity, environment and illumination with the capacity of the crew to execute tasks, the effect of the internal distraction in the success of a task was evaluated by [14] and [15] tested the job commitment.

Studies have been focused in the physiological state of the pilots [16], showing that the lasting sleep deprivation reduces the efficiency of their skills [17], this can be tackled using strategic naps, which benefits the health and welfare of the pilot, guaranteeing the security of the flight [18]. This lines up with the study presented by [19], where pilots mentioned that they felt exhausted during long distance flights. Moreover, social or personal factors (e.g. career ambitions, social culture) could also influence pilot's decision-making [20].

At the same time, long distance flights, flight directions, crew programming, aircraft environment and the company management cause the pilots fatigue [21]. Other authors mention that fatigue and stress are psychosocial risk factors that may generate changes in the body temperature and alter flight conditions [22] [23] [24].

Exposure to a thermal environment have an effect on performance and productivity [25]. The effect of heat exposure on performance change depending on the task, and the duration of the exposure, the acclimatization [26]. Moreover, visual perception and body response are more sensible to the exposure to heat, in contrast with tasks that require the use of memory [27].

[28], [29] and [27], assure that high temperatures in the cabin lead to the decrease of manual expertise and a loss of ability in the flight orientation. They determined that the recognition memory is not affected in environments around $26^{\circ} \mathrm{C}$, but in lower or higher temperatures, it is reduced significantly. [27] also mention that the exposure to heat can lead to physiological responses such as the increase of metabolic rate and corporal temperature, and physical reactions like the reduction of physical capacity to conduct tasks. This could also affect the pilots' cognitive performance.

A study about low temperatures shows that there is a positive effect on the short run on the lasting sleep deprivation, since it keeps the concentration stable during the flight [30], but in general, the cold environmental conditions contributes to dangerous driving behavior [4]. (1)(1)

In the case to heat exposure, the attention and memory of the pilots when performing the flight maneuvers do not disrupt [31]. Although, the following year, Gaoua and his collaborators [32] report another study where, in the case of complex cognitive tasks, there was a reduction in the performance of a pilot exposed to a hot environment. [33] Concluded that when the thermic sensation is not pleasant, the 
pilots' abilities decrease. [27] showed that participants exposed to heat conditions perceived the same risky behaviors to be less risky.

Hutten and collaborators [34], present a panorama about the difficulty of a flight task. They mention that when the difficulty of a task increases, the flight performance of the pilot decreases, since there is a large amount of information that outperform the capacity of the pilot and lead to stress. They also assure that the complexity of the maneuver requires processing of a large amount of information, which challenges the attention, perception, work memory, selection and decision making of the pilots. This was also observed in car drivers were the complexity of the task and the situational characteristics such as expectancy of an event affected the driving behavior [35].

The following table gathers the information related to some experiments where the effect of temperature on the aircrafts pilots was evaluated.

TABLE I

DESCRIPTION OF PRINCIPAL STUDIES, WHERE THE RESPONSE VARIABLE ALSO CORRESPONDS TO TEMPERATURE

\begin{tabular}{lllcc}
\hline \hline $\begin{array}{c}\text { Article } \\
\text { (Citation) }\end{array}$ & \multicolumn{1}{c}{ Factors } & \multicolumn{1}{c}{ Response variable } & $\begin{array}{c}\text { Measured } \\
\text { population }\end{array}$ & $\begin{array}{c}\text { Sample } \\
\text { size }\end{array}$ \\
\hline$[8]$ & $\begin{array}{l}\text { Flight times, Noise levels, } \\
\text { Vibration stimuli }\end{array}$ & $\begin{array}{l}\text { Effects of the noise and the vibration on the pilot's } \\
\text { performance. }\end{array}$ & Pilots & 30 \\
\hline$[28]$ & $\begin{array}{l}\text { Temperature, Mental work } \\
\text { time }\end{array}$ & $\begin{array}{l}\text { Effect of the stress by moderate heat in the mental } \\
\text { performance of pilots. }\end{array}$ & Pilots & 72 \\
\hline $\begin{array}{l}\text { Type of operations, Official } \\
\text { position }\end{array}$ & $\begin{array}{l}\text { Level of fatigue of the flight crew. } \\
{[19]}\end{array}$ & Flight crew & 1893 \\
\hline$[5]$ & Temperature, Age, Gender & Emergency performance (departure of a helicopter) & College students & 11 \\
\hline$[32]$ & Temperature, Reaction time & Cognitive performance of participants. & Volunteers & 18 \\
\hline$[17]$ & Sleep deprivation time & Pilots' performance on cognitive tasks. & Airforce pilots & 10 \\
\hline$[4]$ & Temperature, Age, Gender & Pilots' performance. & Pilots & 50 \\
\hline$[27]$ & Temperature, Age, Gender & Risk behavior regarding the exposure to heat. & College students & 17 \\
\hline$[30]$ & $\begin{array}{l}\text { Temperature, Age, Gender, } \\
\text { Task time }\end{array}$ & $\begin{array}{l}\text { Drowsiness level perceived by the pilots in a cold } \\
\text { environment. }\end{array}$ & $\begin{array}{l}\text { Workers of the } \\
\text { BMW Group }\end{array}$ & 34 \\
\hline$[10]$ & $\begin{array}{l}\text { Age, Flight experience, } \\
\text { Noise frequency }\end{array}$ & Pilots' performance. & Pilots & 14 \\
\hline \hline
\end{tabular}

In this way, the present experimental study aims to evaluate the effect of the temperature over the development of the maneuvers that execute the pilots of aircrafts during their flights, considering the difficulty of the tasks executed.

\section{DATA COLlection Methodology}

\section{A. Description of the sample}

Ten airplane pilots where selected with a certificated formation. The volunteers were eight men and two women. The age range was between 22 and 50 years old with an average experience of 420 flight hours.

\section{B. Factors}

TABLE II

FACTORS AND LEVELS

\begin{tabular}{ccc}
\hline \hline Treatment & Temperature & Maneuver difficulty \\
\hline 1 & Low $\left(21^{\circ} \mathrm{C}\right)$ & Basic \\
2 & Low $\left(21^{\circ} \mathrm{C}\right)$ & Advanced \\
3 & High $\left(35^{\circ} \mathrm{C}\right)$ & Basic \\
4 & High $\left(35^{\circ} \mathrm{C}\right)$ & Advanced \\
\hline \hline
\end{tabular}

The factor corresponding to the difficulty of the maneuver refers to the degree of complexity of the tasks, as well as the number of tasks during a flight period. For this factor, there is a basic and an advanced level.
Four maneuvers where chosen: two basic and two advanced, which are described in the airplane manual CESSNA 182RG. In each process, the pilots had different maneuvers to avoid the learning bias. Each participant only performed one basic and one advanced maneuver for each level of temperature.

The two levels of temperature used in this research are a reference of the previous reported study [5], where $21^{\circ} \mathrm{C}$ and $35^{\circ} \mathrm{C}$ correspond to the thermoneutral and hot temperature respectively. This factor has a purpose of generating microenvironments of room temperature and heat to measure its influence on the performance of piloting maneuvers. The temperature was modified every time a pilot finished the basic or advanced maneuver.

During each trial, the simulated control tower had continuous radio communication with the pilots to guide them on which maneuvers they had to accomplish.

\section{Trial Design.}

The flight instruction was divided in two maneuvers defined as basic and advanced. These two types of maneuvers were tested at each level of temperature. This factorial design let proof if there is interaction between these two factors. 


\section{Measurement Instruments.}

The thermal stress measuring device EXTCH, HT30 was used to report the environmental temperature and the relative humidity that the pilots were exposed to inside the cabin of the flight simulator. The EXTECH-365515 chronometer helped to take the time spent for each participant to finish the maneuver. The temperature was adjusted during the experiment with a Samsung tower model MY812HLOPWKFSLMX that has three different speeds: low, medium and high. The fan was static inside the cabin.

The simulator for the specified airplane (CESSNA 182RG) was STDD (Static Flight Driving Device). The equipment has an image projector where the participants saw the flight track and the respective scenery of the exterior of the cabin. In addition, it has two lateral screens that project the left and right side of the exterior in a flight simulation.

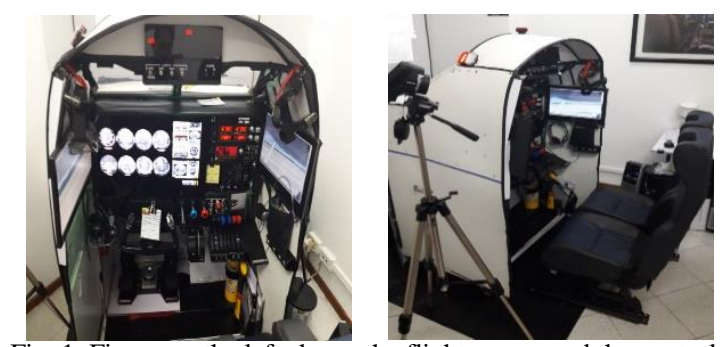

Fig. 1. Figure on the left shows the flight screen and the control commands. Figure on the right shows the right lateral screen of the flight simulator.

\section{E. Experimental design}

A full factorial $2^{2}$ design with the pilots as a blocking factor was implemented. Using the pilots as a blocking factor helps to avoid that skill and experience differences had an impact on the response variable.

\section{F. Data collection.}

The participants where not informed about the difficulty of the tasks beforehand, neither the execution order. For each maneuver, the pilots had a minute to read the instructions. Before the pilot sited in the simulator the temperature was already set.

The combinations of temperature-difficulty were randomized. The temperature was constant during the maneuver to avoid any additional effects on concentration. The time of the task was measured from one minute after they read the instructions until the pilot informs that the maneuver was completed.

The different maneuvers used in this experiment are presented in table III.
TABLE III

MANEUVERS

\begin{tabular}{ll}
\hline \hline Maneuver & Category \\
\hline Front failure with motor & Basic \\
\hline Slow flight & Basic \\
\hline Number eight over pylons & Advanced \\
\hline Half turn & Advanced \\
\hline Number eight over the horizon & Advanced \\
\hline \hline
\end{tabular}

Some STDD simulator's pictures are showed in Fig. 1. and Fig. 2.

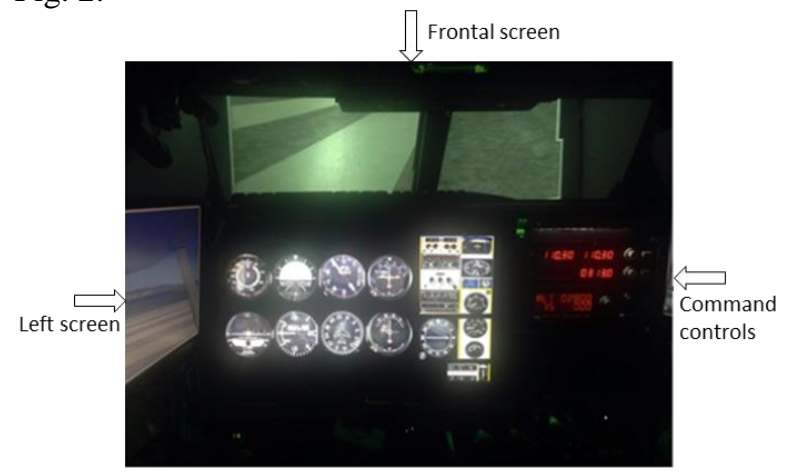

Fig. 2. Simulator STDD. Projection of the frontal screen, left screen and commands control.

\section{G. Statistical Analysis}

First, a descriptive analysis of the data was made. After that, the effect of each factor was tested using analysis variance (ANOVA).

\section{H. Descriptive Analysis}

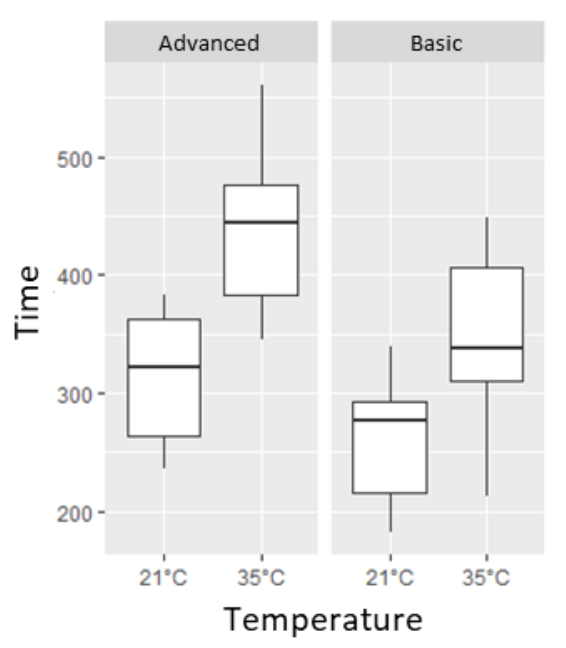

Fig 3. Descriptive analysis, boxplot of the temperature factors and difficulty in respect with the response variable.

The boxplot shows differences in the performance time of the maneuvers depending on the temperature and difficulty factor. For temperatures of $21^{\circ} \mathrm{C}$ and $35^{\circ} \mathrm{C}$, the time spent to do the maneuver was between $288.45 \pm 60.49$ seconds and 
$396.94 \pm 85.01$ seconds, respectively. In the case of difficulty, the times were $307.52 \pm 78.78$ seconds and $377.88 \pm 90.93$ seconds, for each basic and advanced maneuver respectively.

For both difficulty levels, it was possible to observe the similar tendency in the response variable. In the basic level, the room temperature of $21^{\circ} \mathrm{C}$ and heat of $35^{\circ} \mathrm{C}$, the time it took to develop the maneuver was in $263.27 \pm 56.96$ seconds y $351.77 \pm 74.19$ seconds respectively.

\section{Hypothesis testing}

The statistical effects model applied is presented in equation 1 , where, $\tau$ represents the temperature effect, $\omega$ represents the difficulty effect, $\tau \omega$ represents the interaction effect, $\beta$ contains the difference between the pilots and $\varepsilon$ is the error term.

$$
y_{i j k}=\mu+\tau_{i}+\omega_{j}+(\tau \omega)_{i j}+\beta_{k}+\varepsilon_{i j k}(E q 1)
$$

\section{J. ANOVA assumptions}

The ANOVA assumptions such as randomization, heteroscedasticity and normality where confirmed through the prediction vs. residuals and PP plot.

\section{K. Analysis of Variance}

To examine the effect of temperature and the difficulty in the development time of the maneuver, the ANOVA test was used. The $p$ values on table IV show that all elements, excluding the interaction term are significant.

TABLE IV ANALYSIS OF VARIANCE

\begin{tabular}{lccccc}
\hline \hline \multicolumn{5}{c}{ ANOVA } \\
\hline SC & GL & CM & F & p valor \\
\hline Pilots & 115568.275 & 9 & 12840.919 & 9.178 & $<\mathbf{0 . 0 0 1 *}$ \\
\hline Difficulty & 49505.296 & 1 & 49505.296 & 35.383 & $<\mathbf{0 . 0 0 1 *}$ \\
\hline Temperature & 117694.292 & 1 & 117694.292 & 84.121 & $<\mathbf{0 . 0 0 1 *}$ \\
\hline $\begin{array}{l}\text { Difficulty } \\
* \text { Temperature }\end{array}$ & 3991.604 & 1 & 3991.604 & 2.853 & 0.103 \\
\hline Error & 37775.888 & 27 & 1399.107 & & \\
\hline Total & 324535.356 & 39 & & & \\
\hline \hline
\end{tabular}

Both factors, Temperature and Difficulty, were significant. $\mathrm{P}$-value associated with pilots reveal that they have different abilities. This supports the data observed in the boxplot, in presence of heat the performance of the time needed to complete the maneuver increases. Result suggest that there is no significant interaction between factors.

\section{DISCUSSION}

The current results point out that the time pilots need to complete a maneuvers is significantly higher at $35{ }^{\circ} \mathrm{C}$ in contrast with room temperature. These results indicate that heat stress may impair the performance of tasks, which is consistent with the results reported by Taber and colleagues [5] \& Chang and collaborators [27]. Pilots participating in the study also mentioned to have perceived a decrease on their performance when the temperature was higher. This means that at higher temperatures, the performance of the pilots decreases. This is aligned with Pisacaena et al. [29] Wyon et al [28] \& Chang et al. [27] and it is justified by stress, fatigue or other related factor [21].

Maneuvers that are more complicated require more time. With this, we were able to determine that not only the temperature of the environment influences the performance of the pilots, but also the maneuver difficulty.

Several researches declared that exposure to heat could be considered a threat to the safety of workers. In other studies, also shown that heat can generate an increase in unsafe driving rates. The sliding of sweaty palms, the fogging of safety equipment caused by heat and poor physical performance, are usually related to increases in temperature. It should be added that heat stress can increase the levels of irritation and hostility of individuals and their ability to remain alert and focused [32] [27], a point that was confirmed by observation in the experiment where the pilots were clearly affected by the heat.

This was also reflected during the time the pilots were assigned to read the instructions that corresponded to the description of the maneuver that would be carried out, since they stated that during the heat condition, the concentration while reading the instructions and developing the maneuvers was different compared to the ambient temperature condition.

One limitation of this study is the small sample size, which reduce the power to detect true effects. In this way, although the p-value of the interaction was not significant, a 0.103 and the data suggests that, on heat conditions hard task become ever harder. In the current research, there was a difference of $70.94 \%$ in the development times of the advanced maneuvers in the temperatures of $21^{\circ} \mathrm{C}$ and $35^{\circ} \mathrm{C}$.

\section{CONCLUSIONS}

The current study analyzed the influence of temperature on maneuvering time, and therefore on the impact of the performance of aircraft pilots. The findings suggest that according to the analysis of variance, the time of development of a maneuver is not influenced by the interaction between the temperature and difficulty factors. However, it was found that the exposure to the temperature factor of $35^{\circ} \mathrm{C}$ significantly affected the execution of the maneuvers compared to performing maneuvers at a room temperature. This can affect the planning and execution of tasks typical of piloting, in reference to a change in temperature produced by the area and time zone. 


\section{RECOMENDATIONS AND FUTURE INVESTGATIONS}

This research suggest two key points acclimatization can be an important intervention to tackle high temperatures, and aircrafts must include a device to measure the temperature inside the cabin to be able to keep a continuous awareness of heat.

Temperature is a key factor studied several times in the literature; therefore, it is recommended that in subsequent studies, the number of levels of this factor get increased. In the same way, assessing the difficulty factor with more than two levels will be a key point since it has been reported that the complexity of a maneuver can interfere in the working memory, attention and decision making of aircraft pilots.

The p-value of the interaction obtained, 0.103 , could be subject to the number of pilots who participated in the study. It is possible that increasing the sample number and the levels of difficulty and temperature, could lead to verify if, in fact, there is some interaction of temperature and difficulty in the time needed to complete de maneuver.

\section{CONFLICT OF INTEREST}

The authors declare no conflict of interest.

\section{ACKNOWLEDGEMENT}

The authors thank Engineer Diego G. Robledo Mejía, for his constant collaboration, support and interest, during the realization of the experiments. We also wish to thank the company B-Plane (Bogotá D.C.), which allowed the use of the flight simulator STDD (Static Flight Driving Device) where the pilots carried out the tests.

\section{REFRENCES}

[1] Aerocivil, "Aeronautica Civil," 13 Noviembre 2017. [Online]. Available: http://www.aerocivil.gov.co/.

[2] RAC 4, "Reglamentos Aeronáuticos de Colombia," Normas de Aeronavegabilidad y operación de Aeronaves, p. 692, 2017.

[3] IDEAM, "Características Climatológicas De Ciudades Principales Y Municipios Turísticos, pp 8;16," 1 Enero 2018. [Online]. Available: http://www.ideam.gov.co/documents/21021/21789/1Sitios+turistico s2.pdf/cd4106e9-d608-4c29-91cc-16bee9151ddd.

[4] D. Morris and J. Pilcher, "The cold driver: Cold stress while driving results in dangerous behavior," Biol Psychol, vol. 120, pp. 149-155, 2016. DOI: 10.1016 / j.biopsycho.2016.09.011.

[5] M. Taber, N. Dies and S. Cheung, "The effect of transportation suit induced heat stress on helicopter underwater escape preparation and task performance," Applied Ergonomics, vol. 42, no. 6, pp. 883-889, 2011. DOI: 10.1016/j.apergo.2011.02.007.

[6] H. Kharoufah, J. Murray, G. Baxter and G. Wild, "A review of human factors causations in commercial air transport accidents and incidents: From to 2000-2016," Progress in Aerospace Sciences, pp. 1-13, 2018. DOI: 10.1016/j.paerosci.2018.03.002.

[7] Y.-H. Chang, H.-H. Yang and Y.-J. Hsiao, "Human risk factors associated with pilots in runway excursions," Accident Analysis \& Prevention, pp. 227-237, 2016. DOI: 10.1016/j.aap.2016.06.007.

[8] A. Stave, "Effects of Helicopter noise and vibration on pilot performance," NATIONAL AERONAUTICS AND SPACE ADMINISTRATION, pp. 1-87, 1973.

[9] A. Stave, "The effects of cockpit environment on long-term pilot performance," Human Factors, vol. 19, no. 5, pp. 503-14, 1977. DOI: $10.1177 / 001872087701900506$.

[10] J. Ivošević, T. Bucak and P. Andraši, "Effects of interior aircraft noise on pilot performance," Applied Acoustics, vol. 139, pp. 8-13, 2018. DOI: 10.1016/j.apacoust.2018.04.006.

[11] M. Á. Sánchez-Tena, C. Alvarez-Peregrina, M. C. Valbuena-Iglesias and P. Ruisoto Palomera, "Optical Illusions and Spatial Disorientation in Aviation Pilots," Journal of Medical Systems, vol. 42, no. 5, pp. 42-79, 2018. DOI: 10.1007/s10916-018-0935-4.

[12] V. Mellert, I. Baumann, N. Freese and R. Weber, "Impact of sound and vibration on health, travel comfort and performance of flight attendants and pilots," Aerospace Science and Technology, vol. 12, no. 1, pp. 18-25, 2008. DOI: 10.1016/j.ast.2007.10.009.

[13] J. Gaviria and E. Meriño, "Diseño preliminar de la configuración de cabina para la aeronave de entrenamiento primario phaeton PT-01," Ciencia y Poder Aéreo, vol. 4, no. 1, pp. 21-29, 2009. DOI: 10.18667/cienciaypoderaereo.51.

[14] S. Casner and J. Schooler, "Vigilance impossible: Diligence, distraction, and daydreaming all lead to failures in a practical monitoring task," Conscious Cogn, vol. 35, pp. 33-41, 2015. DOI:10.1016 / j.concog.2015.04.019.

[15] . C. Tien-Ming, H. Ci-Yao and Y. Bo-Cheng, "Examining the moderating effects of service climate on psychological capital, work engagement, and service behavior among flight attendants," Journal of Air Transport Management, vol. 67, pp. 94-102, 2018. DOI: 10.1016/j.jairtraman.2017.11.009.

[16] N. Olarte, Y. Cabezas and G. Echeverry, "Factores que intervienen en el desempeño de un piloto bajo diferentes condiciones de vuelo revisión de tema," Ciencia y poder Aéreo, vol. 8, no. 1, pp. 9-20, 2013. DOI: $10.18667 /$ cienciaypoderaereo.2.

[17] N. Lopez, F. Previc, J. Fischer, R. Heitz and R. Engle, "Effects of sleep deprivation on cognitive performance by United States Air Force pilots," Journal of Applied Research in Memory and Cognition, vol. 1, pp. 27-33, 2012. DOI: 10.1016/j.jarmac.2011.10.002.

[18] B. Hartzler, "Fatigue on the flight deck: the consequences of sleep loss and the benefits of napping," Accident Analysis \& Prevention, pp. 309-318, 2014. DOI: 10.1016/j.aap.2013.10.010.

[19] Y. Jin-Ru, H. Chiung-Chi, Y. Hsuan and H. Hero, "An investigation of fatigue issues on different flight operations," Journal of Air Transport Management, vol. 15, no. 5, pp. 236-240, 2009. DOI: 10.1016/j.jairtraman.2009.01.001.

[20] D. Michalski and C. Bearman, "Factors affecting the decision making of pilots who fly in Outback Australia," Safety Science, vol. 68, pp. 288-293, 2014. DOI: 10.1016/j.ssci.2014.03.005

[21] L. Seungyoung and K. Jin Ki , "Factors contributing to the risk of airline pilot fatigue," Journal of Air Transport Management, vol. 67, pp. 197-207, 2018. DOI: 10.1016/j.jairtraman.2017.12.009.

[22] P. Roma, S. Hursh, A. Mead and T. Nesthus, "Analysis of Commute Times and Neurobehavioral Performance Capacity in Aviation Cabin Crew," Federal Aviation Administration, pp. 1-10, 2012.

[23] C. Aguirre, "Estresores laborales y calidad de vida en pilotos hispanoparlantes de aeronaves comerciales.," Repositorio Universidad de Salamanca, pp. 1-226, 2014.

[24] M. Arroyave, "Factores psicosociales intra y extra laborales, estrés y patologías de mayor prevalencia en pilotos y tripulaciones de aerolíneas comerciales: una revisión sistemática 2013 - 2016," Repositorio Institucional UdeA, pp. 1-24, 2016. 
[25] K. Parsons, Human thermal environments: The effects of hot, moderate, and cold environments on human health, comfort and performance, CRC Press, 2002.

[26] J. J. Pilcher, E. Nadler and C. Busch, "Effects of hot and cold temperature exposure on performance: A meta-analytic review," Ergonomics, vol. 45, no. 10, pp. 682-698, 2002. DOI: 10.1080/00140130210158419.

[27] C. Chang, T. Bernard and J. Logan, "Effects of heat stress on risk perceptions and risk taking," Applied Ergonomics, vol. 62, pp. 150157, 2017. DOI: 10.1016 / j.apergo.2017.02.018.

[28] D. Wyon, I. Andersen and G. Lundqvist, "The effects of moderate heat stress on mental performance," Scandinavian Journal of Work Environment \& Health, pp. 352-61, 1979. DOI: 10.5271/sjweh.2646.

[29] V. Pisacanea, L. Kuznetzb, J. Logan, . J. Clark and E. Wissler, "Thermoregulatory models of safety-for-flight issues for space operations," Acta Astronautica, vol. 59, pp. 531-546, 2006. DOI: 10.1016/j.actaastro.2006.04.007.

[30] E. Schmidt, R. Decke and R. Rasshofer, "Psychophysiological responses to short-term cooling during a simulated monotonous driving task," Applied Ergonomics, vol. 62, pp. 9-18, 2017. DOI: 10.1016/j.apergo.2017.01.017.

[31] N. Gaoua, S. Racinais, J. Grantham and F. El Massioui, "Alterations in cognitive performance during passive hyperthermia are task dependent," Int J Hyperthermia., vol. 27, no. 1, pp. 1-9, 2011. DOI: 10.3109/02656736.2010.516305

[32] N. Gaoua, J. Grantham, S. Racinais and F. El Massioui, "Sensory displeasure reduces complex cognitive performance in the heat," Journal of Environmental Psychology, vol. 32, no. 2, pp. 158-163, 2012. DOI: 10.1016/j.jenvp.2012.01.002.

[33] N. Cedeño, E. Acosta and R. Plazas, "Factores que intervienen en el desempeño de un piloto bajo diferentes condiciones de vuelo revisión de tema," Cienacia y Poder Aéreo, pp. 49-57, 2013.

[34] K. Huttunen, H. Keränen, E. Väyrynen, R. Pääkkönen R and T. Leino, "Effect of cognitive load on speech prosody in aviation: Evidence from military simulator flights," Appl Ergon, vol. 42, no. 2, pp. 348-57, 2011. DOI: 10.1016/j.apergo.2010.08.005.

[35] M. Powelleit and M. Vollrath, "Situational influences on response time and maneuver choice: Development of time-critical scenarios," Accident Analysis \& Prevention, pp. 48-62, 2018. DOI: 10.1016/j.aap.2018.09.021.

Zuleny Irene Cuaran Cuaran (B'2015) was born in Cali, Colombia, in 1993. She received the B.S. in material engineering from the University of Valle-Colombia, in 2015. She is currently pursuing the Ph.D. degree in engineering at Pontificia Universidad Javeriana in BogotáColombia.

ORCID: https://orcid.org/0000-0003-2377-0246

Rodolfo Alberto Lopez Pimiento (B'2015) was born in Bogotá, Colombia, in 1993. He received the B.S. in Chemestry from Universidad Distrital-Colombia, in 2015. $\mathrm{He}$ is currently pursuing the master's degree in bioengineering at Pontificia Universidad Javeriana in Bogotá-Colombia.

ORCID: https://orcid.org/0000-0003-2176-1071
Wendy Marcela Fong Amarís ( B'2017) was born in Cartgena, Colombia, in 1994. She received the B.S. in Biology from the University of Atlantico-Colombia, in 2017. She is currently pursuing the master's degree in bioengineering at Pontificia Universidad Javeriana in Bogotá-Colombia.

ORCID: https://orcid.org/0000-0001-7185-9478

Maribel Martinez Lozano (B'2016) was born in Bogota, Colombia, in 1994. She received the B.S. in Physics from the Pedagogical University-Colombia, in 2016. She is currently pursuing the master's degree in bioengineering at Pontificia Universidad Javeriana in Bogotá-Colombia.

ORCID: https://orcid.org/0000-0001-8449-1510

Ricardo Otero-Caicedo (B'2011, M'2013) was born in Pasto, Colombia, in 1990. He received the B.S. in industrial engineering from the Pontificia Universidad Javeriana, in 2011, and the master's degree in industrial engineering in 2013. Since 2014, he has been an assistant professor at Pontificia Universidad Javeriana. ORCID: https://orcid.org/0000-0002-0358-8538. 